\title{
ВСЕСВІТНЯ ІСТОРІЯ
}

УДК $342.72 / 73$

DOI $10.34142 / 2313-2345.2020 .58 .09$

\begin{abstract}
Олійник О. М.
кандидат юридичних наук, доцент, завідувач кафедри суспільно-правових дисциплін і менеджменту освіти Харківського національного педагогічного університету імені Г.С. Сковороди https://orcid.org/0000-0001-8382-9751
\end{abstract}

Бондаренко Наталія Олександрівна кандидат юридичних наук, дочент, доцент кафедри правового забезпечення безпеки бізнесу Київського начіонального торговельно-економічного університету https://orcid.org/0000-0001-9370-301X

\section{ГЕНЕЗА ТА СУЧАСНИЙ РОЗВИТОК КОНЦЕПЦЇ̈ ПОКОЛІНЬ ПРАВ ЛЮДИНИ}

У статті досліджується генеза поколінь прав людини. Автори розглядають підходи провідних країн світу до аналізу історичного розвитку прав людини і формування концепції поколінь. Наведені покоління прав людини в традиційній класифікації, розглянуті різні погляди щуодо віднесення прав людини до того чи іншого покоління. Робиться висновок про те, щзо розвиток поколінь прав людини цее постійний прочес, який визначається розвитком і контекстом певної історичної епохи.

Ключові слова: права людини, покоління прав людини, «негативні права», позитивні права, колективні права, соматичні права людини, ООН.

The article analyzed the genesis of generations of human rights, taken as a basis the most economically developed countries in Europe and North America. The authors examine the approaches of the leading countries of the world to the analysis of the historical development of human rights and the formation of the concept of generations. At the article presents the generations of human rights in the traditional classification, discussed different views on the inclusion of human rights to one or another generation. It is concluded that the development of generations of human rights is an ongoing process, which is determined by the context and development of a particular historical epoch.

Key words: human rights, generation of human rights, "negative rights», positive rights, collective rights, somatic human rights, the United Nations.

Постановка проблеми дослідження, визначається тим, що взаємодія держави й особи пронизує всю історію існування людства. Ще давньогрецькі філософи, створюючи концепції ідеальних держав і суспільств, насамперед, виділяли співвідношення держави, суспільства й особи. Саме завдяки державі й суспільству людина стає «особистістю». Вступаючи в життя, спочатку людина освоює спочатку мінімум знань, професійні навички, а потім здобуває сукупність статусів в економіці, культурі, політиці. При цьому особа характеризується сукупністю освоюваних соціальних зв'язків; через обсяг знань, досвід, професійні орієнтації, індивідуальні особливості, світоглядний потенціал тощо. Таким чином, якщо поняття «людина» - біологічне, те «особа» це вже, безумовно, соціальне явище.
Разом 3 формуванням поняття «особа» у науковий обіг вводиться поняття «права людини», які й відображають розвиток прав особи в суспільстві й державі. В результаті наукової систематизації прав людини в історичному сенсі й з'явилася теорія трьох поколінь прав людини. На початку XXI ст. деякі дослідники починають виділяти й четверте покоління прав людини [6, с.211].

Аналіз актуальних досліджень 3 icторії концепції поколінь прав людини свідчить, що ця проблема була предметом досліджень низки науковців. Окремі аспекти цього питання висвітлилися у працях М.М.Анісімова, С.Б.Булеци, В.В.Заборовського, В.І.Крусса, О.Ф.Скакун, Ю.М.Тодики, Ю.I.Турянського, H.L.Mencken, K.Vasak та інших авторів. 
Метою статті $\epsilon$ історичне та теоретичне дослідження формування концепції поколінь прав людини на протязі XVIII-XXI ст. та поступове юридичне врегулювання цих прав провідними країнами світу та основних перешкод, які постають перед державами, що не дають їм змоги остаточно закріпити права людини четвертого покоління на законодавчому рівні.

Виклад основного матеріалу. Термін «права людини» порівняно новий. Його стали вживати після Другої світової війни, коли в 1945 р. була створена Організація Об'єднаних Націй. I тоді ж вводиться інший термін - «природні права». У такий же спосіб було замінено більш пізніше вираження «права чоловіка», тому що воно не враховувало права жінок [10, с.13].

Фахівці із прав людини можуть простежити історичне походження цієї концепції ще 3 часів Стародавньої Греції та Рима. Тоді вона була тісно пов'язана 3 доктринами природного права грецького стоїцизму. Це була філософська школа, заснована Зеноном з Кітіону, який вважав, що весь всесвіт пронизує універсальна творча сутність. Тому поведінку людини необхідно розглядати згідно із законами природи й погоджувати 3 ними [13, с.130-131]. Елліністичний стоїцизм суттєво вплинув на формування й поширення римського права, можна сказати, що він передбачав існування природного права й відповідав jus gentium («права народів») - універсальному праву, яке виходило за межі прав громадянства. Наприклад, римський юрист Ульпіан вважав, що природне право - це право, яке дається від природи а не від держави й воно дається всім людським істотам, незалежно від того чи римські вони громадяни або ні [11, с.182].

Однак доктрина природного права почала тісно пов'язувати з ліберальними політичними теоріями про природні права лише в часи пізнього Середньовіччя. Для того щоб ідея про права людини, тобто про природні права, як загальна соціальна потреба й реальність, постійно домінувала, повинні були відбутися фундаментальні зміни в переконаннях і практиці суспільства, що відбулося в період Відродження й у часи занепаду феодалізму - період від XIII ст. до Вестфальского миру (1648р.). Коли опір релігійному догматизму й політико-економічній рабській залежності поступово стало трансформуватися в ліберальні поняття свободи й рівноправності, особливо щодо володіння й користування власністю, лише тоді по-справжньому були закладені основи, які ми сьогодні називаємо правами людини. Протягом цього періоду відбувся перехід від обов'язків природного права до прав природного права [9, с.14].

Однак, лише в XVII - XVIII ст. була розроблена модерністська концепція природного права, яка передбачала наділення усіх людей природними правами. У іï розробці особливу участь взяли такі філософи й просвітителі як Джон Локк, Шарль Монтеск'є, Вольтер і Жан-Жак Руссо. Найбільший вплив, на нашу думку виявила творчість Дж. Локка. У своїх працях, пов'язаних з революцією 1688 г. (так званою «Славною революцією»), він послідовно доводив, що кожній особистості належать певні права (оскільки вона, як людська істота, існувала в «природному стані» ще до того, як людство стало громадянським суспільством); що основними серед них є право на життя, свободу й власність; що після появи громадянського суспільства ( відповідно до «суспільної угоди»), людство відмовилося на користь держави не від самих прав, а лише від реалізації цих природних прав, і що нездатність держави забезпечити ці зарезервовані права (держава саме зобов'язалася забезпечити інтереси своїх громадян) породжує право на відповідну народну революцію [5, с.264267]. Разом із Ш. Монтеск'є Дж. Локк також розробив концепцію поділу влади на три гілки: законодавчу, виконавчу й судову. Що стосується прав людини, французький філософ вважав, що «свобода - це право робити все, що дозволене законами» [6,c.289291]. Це визначення не втратило свою актуальність і в теперішній час.

Філософи, спираючись на настанови Локка й інших вчених-просвітителів та маючи значну віру та здоровий глузд, рішуче критикували релігійний i науковий догматизм, нетерпимість, цензуру й соціальноекономічні обмеження. Вони прагнули діяти на основі універсальних справедливих принципів, які гармонійно управляють природою, людством і суспільством, а теорія 
невідчужуваних «прав людини» стала їх основною етичною й соціальною стратегією.

Не дивно, що всі ці ліберальноінтелектуальні пошуки мали великий вплив на західний світ кінця XVIII - початку XIX ст. Разом з прикладом англійської революції 1688 р. і Білля про права, який став іiї результатом, вони сприяли логічному обгрунтуванню революційної хвилі, яка на той час охопила Захід, а особливо Північну Америку й Францію. Томас Джефферсон, який аналізував ідеї Дж. Локка й Ш. Монтеск'є стверджував, що його співвітчизники - «вільні люди, які претендують на права, які випливають із природного права, а не $\epsilon$ подарунком верховного судді» [9,c.15]. Ця ж ідея була закріплена в Декларації незалежності, проголошеній тринадцятьма американськими колоніями 4 липня 1776 р.: «В ній підкреслювалося, що «ми вважаємо очевидною істиною, що всі люди створені рівноправними, що вони наділені Богом певними не відчужуваними правами, до яких належать життя, свобода й прагнення щастя» [12, с.132-133]. Маркіз де Лафаєт - близький друг Джорджа Вашингтона, який переживав 3 ним труднощі американської війни за незалежність, - повторив гасла англійської й американської революцій у Декларації прав людини й громадянина Франції від 26 серпня 1789 р. Підкреслюючи, що «люди народжуються й залишаються вільними й рівними в своїх правах», у цій декларації проголошувалось: «мета кожної політичної асоціації полягає в збереженні природних i невід'ємних прав людини» [12,c.88-89]. Декларація визначала ці права як «Свободу, Власність, Безпеку й Опір гнобленню». Поняття «воля» включала свободу слова, об'єднань, релігійну свободу й свободу від свавільного арешту й тюремного ув'язнення (випереджаючи Білль про права (1791р.) [12,с.153-155], прийнятий як додаток до Конституції Сполучених Штатів 1787 р.) [10, с. 189-199].

Можна підсумувати, що традиції прав людини є продукт свого часу. Вони відображають процеси історичної безперервності й змін i, як предмет кумулятивного досвіду, допомагають надати їм зміст й форму. Таким чином, щоб краще зрозуміти форми й законний обсяг прав людини корисно про- аналізувати основні школи, які визначили традиції прав людини, починаючи з періоду Відродження.

Особливо корисним щодо цього є поняття «трьох поколінь прав людини». Цей термін ввів в 1970-х рр. Карел Васак, чеський юрист і перший генеральний секретар Міжнародного інституту прав людини в м. Страсбурзі (Франція) [15]. Три покоління прав людини, на його думку, співвідносяться із трьома ідеалами Французької революції: свободою, рівністю й братерством [16,Р.837,839]. Модель Васака, звичайно лише спрощене відображення надзвичайне складного історичного періоду, але дає можливість створити систему розвитку прав людини в контексті розвитку держави й суспільства.

Перше покоління громадянських і політичних прав веде свій початок від зазначених вище реформістських теорій XVII і XVIII ст., пов'язаних $з$ англійською, американською й французькою революціями. Перше покоління включає особисті права, що випливають із природних прав і створених на основі позитивного права політичних прав. Вони знаходять свою конкретизацію в законодавстві демократичних держав. Мова йде про особисті (громадянські) і політичні права: право на свободу віросповідання, на участь у керуванні державними справами, на рівність перед законом і судом, на життя, свободу й безпеку особи, від свавільного (незаконного) арешту, затримання. Ці права виразили так звану «негативну волю» - тобто вони поставили обов'язком держави втримуватися від втручання в сферу особистої свободи. Це, наприклад, добре відображене коротким твердженням, яке приписується Х. Л. Менкену - «будь-який уряд, звичайно ж виступає проти свободи» [14, P.145]. Таким чином, до цього першого покоління ставляться заявлені права, викладені в статтях 2-21 Загальної Декларації прав людини [3]. До першого покоління прав також можна віднести право на власність i будь-яка спроба позбавити людину власності $є$ незаконною дією. Кожне із цих прав відстоювало інтереси, за які й була боротьба під час Американської й Французької революцій, а також інтереси, важливі для розвитку капіталізму. Однак у цій концепції пер- 
шого покоління головним є поняття свободи, яке захищає особистість (або групу осіб) від зловживань і поганого ставлення до них політичних влади. Ця основна правова цінність у наш час записана в конституціях більш ніж 180 країн - тобто є практично у всіх конституціях сучасного світу [9, с. 21]. Вона домінує в більшості міжнародних декларацій і угод, які стосуються прав людини прийнятих після Другої світової війни. Це західна ліберальна концепція прав людини, яку іноді представляють у романтичному світлі, як тріумф індивідуалізму ГоббсаЛокка над статизмом Гегеля. Друге покоління економічних, соціальних і культурних прав веде свій початок від соціалістичної традиції, яка намітилася серед сенсімоністів у Франції на початку XIX ст. Ці права сформувалися в процесі боротьби народів світу за поліпшення свого економічного рівня (кінець XIX - початок XX ст.) - до них відносяться соціально-економічні права. Вперше вони були закріплені у конституціях соціалістичних країн. Це такі права як право на працю, освіту, відпочинок, на захист материнства та дитинства.

Історично ця традиція протиставляється першому поколінню громадянських і політичних прав. Друге покоління прав людини сприймається в більш позитивному («право на»), ніж в негативному («воля від») аспекті. Ці права вимагають втручання держави в забезпечення рівної участі в створенні й розподілі відповідних цінностей. Показовими для характеристики даної моделі є права людини, викладені в статтях 2227 Декларації ООН прийнятої 10 грудня 1948 р. [3], такі як право на соціальну безпеку, право на працю й захист від безробіття, право на відпочинок і дозвілля, у тому числі на періодичну оплачувану відпустку, право на гідний рівень життя, який забезпечує здоров'я особи і його родини, право на освіту і на захист наукової, літературної й художньої продукції діяльності особи тощо.

Однак, як і всі громадянські й політичні права першого покоління не правильно характеризувати їх «негативними правами». Пояснюється це тим, що усі права, які належать до другого покоління економічних, соціальних і культурних прав, по суті, не можуть мати поняття «позитивні права».
Наприклад, право на вільний вибір зайнятості, право створювати професійні союзи й брати участь у них, право вільної участі в культурному житті суспільства у своїй основі не вимагають позитивних дій держави для забезпечення задоволення цих прав. Однак, більшість прав другого покоління, відповідно до критеріїв справедливого розподілу благ, вимагають обов'язкового державного втручання про виділення необхідних ресурсів. Адже ці права належать до категорії скоріше матеріальних, ніж не матеріальних цінностей. Таким чином, права другого покоління у своїй основі $\epsilon$ вимогами соціальної рівності. Інтернаціоналізація цих прав відбулася 3 певним запізненням, частково через соціалістичний вплив у нормативній сфері міжнародних відносин. Але 3 виходом на глобальну арену країн третього світу, які діяли під гаслом «революцій великих очікувань», ці права почали інтенсивно удосконалюватися.

Зрештою, третє покоління солідарних прав базується на двох попередніх поколіннях прав, пов'язує їх між собою й поновому їх концептуалізує. Однак краще розглядати це покоління як юридичну категорію у стадії формування - результат одночасного підйому й занепаду націй-держав другої половини XX ст. Третє покоління прав одержало своє вираження в статті 28 Загальної Декларації прав людини ООН, яка проголошує, що «кожний має право на громадський і міжнародний порядок, у якому права, викладені в цій Декларації, можуть бути повністю реалізовані». Третє покоління охоплює нині шість прав. Три 3 них відображають націоналізм країн третього світу і їх вимоги щодо перерозподілу влади, багатства й інших важливих цінностей: право на політичне, економічне, соціальне й культурне самовизначення; право на участь і одержання прибутків від «загальної спадщини людства» (загальний навколоземний простір; наукова, технічна й інша інформація й прогрес; культурні традиції, пам'ятки й пам'ятники). Наступні заявлені права третього покоління - право на мир, право на здорове й збалансоване навколишнє середовище й право на гуманітарну допомогу у випадку катастроф - дають нам можливість зрозуміти, що нації-держави нездатні ефек- 
тивно вирішувати найбільш складні проблеми самостійно без участі міжнародного співтовариства в сучасному світі.

Всі шість вищевикладених прав - колективні права, які вимагають загальних зусиль усіх соціальних сил на планетарному рівні. Однак кожне з них виявляє як індивідуальну, так і колективну сторону. Наприклад, забезпечення нового міжнародного економічного порядку, який усуне перешкоди на шляху економічного й соціального розвитку заявлених прав, можна вважати колективним правом усіх країн і народів (особливо розвиваючих країн). Можна також стверджувати, що одержання користі від політики розвитку, яка базується на задоволенні людських матеріальних і нематеріальних потреб, це індивідуальне право всіх людей. Коли, наприклад, право на самовизначення й право на гуманітарну допомогу знаходить своє відображення, як на законодавчому, так і на моральному рівні, більшість із цих солідарних прав за своїм характером скоріше бажані, чим забезпечені судовою владою, і мають лише неоднозначний юридичний статус міжнародних норм прав людини.

Таким чином, на різних етапах сучасної історії - після «буржуазних» революцій XVII і XVIII ст., соціалістичних революцій першої третини XX в. та в 1940-50-ті pp. i антиколоніальних революцій, які почалися незабаром після закінчення Другої світової війни, - зміст прав людини визначався в цілому. Нові елементи прав людини розбудовувались шляхом розширення й додавання. Відображаючи розвиток усвідомлення того, які саме цінності в різні історичні періоди вимагали найбільшого заохочення й захисту, історія змісту прав людини також показує періодичні вимоги всього людства про безперервність і стабільність.

Між двома першими й третім поколіннями прав людини є взаємозалежність, здійснювана через принцип: реалізація колективних прав не повинна обмежувати права й свободи особи.

У XXI ст. триває процес виникнення й закріплення нових прав особистості, тому деякі дослідники виділяють четверте і навіть п'яте покоління прав людини [7, с.213214]. Пояснюється це тим, що разом з роз- витком і поглибленням права на інформаційний простір нашої планети, на надання різних послуг, заснованих на інтелектуальних інформаційних технологіях (у тому числі новітніх технологічних дослідженнях). Так у технологіях зв'язку, використання глобальної мережі «Інтернет», забезпечення інформаційних відносин усередині країни й за кордоном, розширюються колективні права людини. Активно почалося становлення прав людини, пов'язаних 3 науковими відкриттями в області мікробіології, медицини, генетики й т.п. Ці права - результат втручання в психофізіологічну сферу життя людину (наприклад, право людини на штучну смерть (евтаназія), право жінки на штучне запліднення й виношування дитину для іншої родини й ін.).

Ці права теж мають межі. Наприклад, у багатьох країнах законодавчо введена заборона клонування людини й установлення інших правових меж щодо інших прав цього покоління.

Права четвертого покоління прав людини ще називають соматичними ( від грец. Soma - тіло), яка досліджує основоположні питання, пов'язані з тілом людини, зокрема трансплантацію органів (трансплантологію), стерилізацію і кастрацію [8, с.129].

Одне 3 найбільш повних і новаторських визначень соматичних прав дав російський вчений В.I.Крусс, трактуючи їх як права людини розпоряджатися своїм тілом, включаючи його модернізацію, реставрацію, реконструкцію і розширення функціональних можливостей, шляхом використання технічних і медичних засобів [4].

Змістовно соматичні права розширюють систему особистих прав людини і громадянина. Серцевину особистих прав складають право на життя і гідність особистості, право на свободу і особисту недоторканність, свобода совісті.

Саме вони, очевидно, є базовими, родовими правами для особистісних прав тут то і народжується перше протиріччя. Традиційна система особистих прав, як і раніше, виглядає досить струнко і несуперечливо. Абсолютизація цих прав привела до конституційної констатації неможливості їх обмеження, визнання їх невідчужуваності. Нова ж система соматичних прав включає в 
себе елемент відчужуваності особистих прав першого покоління. Це стосується, перш за все, права на життя. Безумовно, що право на смерть (суїцид, евтаназія) вступає в пряме протиріччя з правом на життя, опосередковано праву на життя суперечать також негативні репродуктивні права (аборт, стерилізація) [1].

Можна стверджувати, що кожне із цих чотирьох поколінь прав не однаково прийнятно для всіх, або що вони або їх окремі елементи завжди й усюди знаходять однакове позитивне відношення. Наприклад, деякі захисники прав першого покоління схильні виключати права другого й третього покоління зі свого визначення прав людини загалом (або, принаймні, називають їх другорядними). У той же час багато вчених не визнають появу прав четвертого та особливо п'ятого поколінь. Зокрема, це пояснюється складностями, які зустрічаються в процесі реалізації цих прав. Прихильники прав першого покоління, які виступають за природне право й традиції невтручання, небайдужі до думки, що права людини у своїй основі незалежні від громадянського суспільства і $є$ індивідуалістичними, тобто тільки вони становлять класичні права особистості. I навпаки, захисники прав другого, третього й четвертого поколінь вважають, що права першого покоління, принаймні, на рівні загальної практики, приділяють недостатньої увагу матеріальним потребам людей і використовуються несправедливими національними, транснаціональними й міжнародними суспільними інституціями в якості легітимізуучих інструментів і це «буржуазна ілюзія». Подібним чином, не виключаючи права першого покоління зі свого визначення прав людини, вони як звичайно надають цим правам низький статус i, відповідно, трактують їх як хронологічно віддалену мету, досягнення якої можливо лише після поступового здійснення фундаментальних економічних і соціальних перетворень, які повністю будуть реалізовані лише в віддаленому майбутньому.

Зрештою, жоден з діючих або запропонованих на сьогоднішній день механізмів прав людини, нічого не вказує про легітимність або впорядкування прав, яких вони стосуються, за винятком прав, які за міжнародною згодою визначені як невід'ємні й тому більш фундаментальні ніж інші (наприклад, свобода від свавільного або незаконного позбавлення життя, від катування й нелюдського або принизливого відношення й покарання, свобода від рабства, від тюремного ув'язнення за борги). Імовірно, коли запитання стосується проблеми здійснення заявлених прав, серед юристів, філософів i політологів не існує єдиної думки щодо їхньої легітимності й ієрархії.

На нашу думку, можна погодитись 3 С.Б.Булецею та В.В.Заборовським, що права людини як індивіда (перше покоління прав), громадянина (друге покоління) та як учасника соціуму (третє покоління) трансформувалися у права всього людства (четверте покоління прав). Ці дослідники переконані, що четверте покоління прав людини є тими ж особистісними, громадянськими та суспільними правами, які з розвитком суспільства перейшли ту грань, яка до цього стримувала їх реалізацію, зокрема суспільну мораль та релігію, що і дає змогу виокремити їх у «граничне» (заключне) покоління прав [2, с.11].

Таким чином, легітимність прав особи й заявлені серед них пріоритети визначаються контекстом певної епохи. Оскільки люди в різних частинах планети відстоюють і поважають ті або інші права людини відповідно до різних процедур і практикою, ці питання цілком залежать від часу, місця, обставин, рівня суспільно-економічної кризи й інших причин. При цьому взаємини держави й особи в історичному генезисі через покоління права людини показують, що в міру розвитку прав особистості їх кількість і розповсюдження в різні сфери суспільного й соціального життя, на нашу думку, тільки збільшується. Про це переконливо свідчить і поява четвертого покоління прав людини. 3 іншого боку гармонійний розвиток особистості можливо тільки в правовій демократичній державі й розвинутому громадянському суспільстві.

\section{ЛІТЕРАТУРА}

1. Анисимов Н.Н. К вопросу о позитивном закреплении соматических прав человека. Новое слово в науке: стратегии развития. 2019. URL: https://in

teractive-plus.ru/e-articles/662/Action662-519408.pdf (дата звернення: 17.01.2020). 
2. Булеца С.Б., Заборовський В.В., Стойка А.В. Деякі проблемні питання правового захисту прав людини четвертого покоління. Науковий вісник Ужгородського національного університету. Серія: Право. 2019. Вип. 55. Т. 1. С. 10-14.

3. Всеобщая декларация прав человека. Голос України від 10.12.2008. № 236.

4. Крусс В.И. Личностные (соматические) права человека в конституционном и философско-правовом измерении: к постановке проблемы. Государство и право. 2000. №10. С. 43-50.

5. Локк Дж. Сочинения: В 3-х т. М.: Мысль, 1988. Т. $3.668 \mathrm{c}$.

6. Монтескье Ш.Л. Избранные произведения / под ред. М.П. Баскина. М.: Госполитиздат, 1955. 843 с.

7. Скакун О. Ф. Теорія держави і права (Енциклопедичний курс). Х.: «Еспада«Ай Бі», 2006. 776 с.

8. Турянський Ю. І. Соматичні права людини в сучасній доктрині конституціоналізму: теоретикоправове дослідження: дис. ... доктора юрид. наук: 12.00.01 / Юрій Іванович Турянський. - Львів, 2020. $482 \mathrm{c}$.

9. Уетсон Бернс Г. Права людини: концепції, підходи, реалізація: пер. $з$ англ. / під ред. Б. Зізік. К.: Вид-во «Ай Бі», 2003. 262 с.

10. Хрестоматия по истории государства и права за- рубежных стран / под ред. 3.М. Черниловского. М.: Юридическая литература, 1984. 472 с.

11. Хрестоматия по истории государства и права зарубежных стран (Древность и Средние века) / Составитель: В. А. Томсинов. М.: ЗЕРЦАЛО, 1999. $480 \mathrm{c}$.

12. Хрестоматия по истории государства и права зарубежных стран (Новое и Новейшее время) / Составитель: Н. А. Крашенинникова. М.: ЗЕРЦАЛО, 1999. $592 \mathrm{c}$.

13. Чанышев А.Н. Курс лекций по древней и средневековой философии: учеб. пособие для вузов. М.: Высшая школа, 1991. 512 с.

14. Mencken H.L. A Mencken Chrestomathy. N.Y.: Alfred A.Knopf, 1949. 627 p.

15. Vasak K. Human Rights: A Thirty-Year Struggle: the Sustained Efforts to Give Force of the Universal Declaration of Human Rights The UNESCO Courier: a window open on the world. 1977. P. 29. URL: https://unesdoc.unesco.org/ark:/48223/

pf0000048063/PDF/074816engo.pdf.multi.nameddes $\mathrm{t}=48063$ (дата звернення: 17.01.2020).

16. Vasak K. Pour une troisieme generation des droits de l'homme // Studies and Essays on International Humanitarian Law and Red Cross Principles / Ed. by C. Swinarski. Hague, 1984.

\section{REFERENCES}

22. Anisimov, N.N. (2019)/ K voprosu o pozitivnom zakreplenii somaticheskih prav cheloveka [On the question of the positive consolidation of somatic human rights]. Novoe slovo $\mathrm{v}$ nauke: strategii razvitiya - New word in science: development strategy URL: https://interactive-plus.ru/e-articles/ 662/Action662-519408.pdf (data zvernennya: 17.01.2020) [in Russian].

23. Buletsa, S.B., Zaborovskyi, V.V., Stoika, A.V. (2019). Deiaki problemni pytannia pravovoho zakhystu prav liudyny chetvertoho pokolinnia [Some problematic issues of legal protection of human rights of the fourth generation]. Naukovyi visnyk Uzhhorodskoho natsionalnoho universytetu Scientific Bulletin of Uzhorod National University. Seriia: Pravo, 55, Vol. 1, 10-14 [in Ukrainian].

24. Vseobschaya deklaratsiya prav cheloveka (2008). [Universal Declaration of Human Rights]. Holos Ukrainy - Voice of Ukraine. 236 [in Russian].

25. Kruss, V.I. (2000). Lichnostnyie (somaticheskie) prava cheloveka $\mathrm{v}$ konstitutsionnom i filosofskopravovom izmerenii: $\mathrm{k}$ postanovke problemyi [Personal (somatic) human rights in the constitutional and philosophical-legal dimension: to the problem statement]. Gosudarstvo i pravo - State and law. 10. 43-50 [in Russian].

26. Lokk, Dzh. (1988). Sochineniya [Essays]. (Vol. 3). Moscow: Myisl [in Russian].

27. Monteske, Sh.L. (1955). Izbrannyie proizvedeniya [Selected works]. M.P. Baskin (Ed). Moscow: gos. izd-vo pol. lit-ryi. [in Russian].

28. Skakun, O. F. (2006). Teoriia derzhavy i prava (Entsyklopedychnyi kurs) [Theory of state and law (Encyclopedic course)]. Kharkiv: «Espada«Ai Bi» [in Ukrainian].
29. Turianskyi, Yu. I. (2020). Somatychni prava liudyny v suchasnii doktryni konstytutsionalizmu: teoretykopravove doslidzhennia [Somatic human rights in the modern doctrine of constitutionalism: theoretical and legal research] Doctor's thesis. Lviv [in Ukrainian].

30. Uetson Berns, H. (2003). Prava liudyny: kontseptsii, pidkhody, realizatsiia [Human rights: concepts, approaches, implementations]. B. Zizik. (Ed). Kiev: «Ai Bi» [in Ukrainian].

31. Chernilovskiy, Z.M. (Eds.). (1984) Hrestomatiya po istorii gosudarstva $i$ prava zarubezhnyih stran [Reader of the history of the state and law of foreign countries]. Moscow: Yuridicheskaya literatura [in Russian].

32. Tomsinov V.A. (Eds.). (1990) Hrestomatiya po istorii gosudarstva $i$ prava zarubezhnyih stran (Drevnost $i$ Srednie veka) [Reader of the history of the state and law of foreign countries (antiquity and middle ages)]. Moscow: ZERTSALO [in Russian].

33. Krasheninnikova, N. A. (Eds.). (1999) Hrestomatiya po istorii gosudarstva $i$ prava zarubezhnyih stran (Novoe $i$ Noveyshee vremya) [Reader of the history of the state and law of foreign countries (new and modern times)].Moscow: ZERTSALO [in Russian].

34. Chanyishev, A.N. (1991) Kurs lektsiy po drevney $i$ srednevekovoy filosofii: ucheb. posobie dlya vuzov [Course of lectures on ancient and medieval philosophy]. Moscow: Vyisshaya shkola [in Russian].

35. Mencken, H.L. (1949) A Mencken Chrestomathy. New York: Alfred A.Knopf, [in English].

36. Vasak, K. (1977) Human Rights: A Thirty-Year Struggle: the Sustained Efforts to Give Force of the Universal Declaration of Human Rights The UNESCO Courier: a window open on the world. 
URL: https://unesdoc.unesco.org/ark:/48223/pf0000 048063/PDF/074816engo.pdf.multi.nameddest $=4806$ 3 (data zvernennya: 17.01.2020) [in English].
37. Vasak, K. (1984) Pour une troisieme generation des droits de l'homme // Studies and Essays on International Humanitarian Law and Red Cross Principles / Ed. by C. Swinarski. Hague [in French].

Мірошніченко С.B. кандидат історичних наук, доцент кафедри всесвітньої історії Харківського національного педагогічного університету імені Г.С. Сковороди https://orcid.org/0000-0002-9384-7491

\section{АЛГОРИТМ УПРОВАДЖЕННЯ ДИСТАНЦЙНОГО НАВЧАННЯ ПРИ ВИКЛАДАННІ КУРСУ «ІСТОРІЯ СТАРОДАВНІХ ГРЕЦІЇ ТА РИМУ»}

У статті визначено законодавчу базу регламентації дистанційного навчання в Україні, його переваги та основні елементи, коло авторів, алгоритм та основні аспекти впровадження курсу «Історія Стародавніх Греції та Риму» в навчальний прочес із використанням як окремих сервісів, які надають комплексне забезпечення навчального прочесу, та і допоміжних задля залучення максимальної кількості стандартних онлайн та офлайн сервісів для більш ефективної організації навчального прочесу, зокрема, і платформи Mоодle. Сформульовані принщипи впровадження курсу на цій платформі, його елементи та змістове наповнення, визначені переваги та недоліки його використання як під час навчальних занять, так і під час впровадження його як елементу самостійної роботи, а також описаний алгоритм проведення іспиту в дистанційному форматі.

Ключові слова: дистаниійне навчання, Moodle, сервіси Google, Zoom, LearningApps.

In the article the legislative base of regulation of the controlled from distance studies is certain in Ukraine, his advantages and basic elements, circle of authors, algorithm and basic aspects of introduction of course "History of Ancient to Greece and Rome» in an educational process with the use as separate services that give the complex providing of educational process, and auxiliary for the sake of bringing in of maximal amount of standard online and of лайн services for more effective organization of educational process, in particular, and platform Moodle. The set forth principles of introduction of course are on this platform, his elements and rich in content filling, certain advantages and lacks of his use both during lessons and introduction of him as element of independent work, and also the described algorithm of realization of examination in distance.

Keywords: distance education, Moodle, Google services, Zoom, LearningApps.

Постановка проблеми. На сучасному етапі інноваційна діяльність $є$ обов'язковим елементом для будь-якої професійної діяльності. У навчальному процесі це перш за все реалізується у теоретичній розробці й практичному втіленні нових підходів і алгоритмів у мету, зміст, методи і форми взаємодії здобувача освіти та його викладачів.

Одним із видів інновацій в організації професійної освіти є введення дистанційного навчання.

Через поширення вірусу Covid-19 із березня 2020 року всі країни почали запроваджувати карантинні заходи, що призвело до закриття на невизначений час усіх навчальних закладів. Вони змушені були за короткий термін перейти на дистанційний навчальний процес. Після послаблення карантину у світі стало зрозуміло, що людст- во перейшло на нову стадію розвитку, де дистанційне навчання буде відігравати велику, якщо не визначальну, роль.

В Україні дистанційна освіта ще в 2000 р. була затверджена Концепцію розвитку дистанційної освіти в Україні, в якій було обгрунтовано доцільність, мету, основні завдання та очікувані наслідки створення і впровадження такої системи [Концепція розвитку 2000]. У 2013 р. вийшло уточнене й конкретизоване «Положення про дистанційне навчання», в якому деталізовано науково-методичне забезпечення й особливості організації навчального процесу 3 використанням технологій дистанційного навчання.

Наразі процес дистанційної освіти регламентується в основному Законом України про освіту, Положенням про дистанцій- 